\title{
Anti-adult T-cell leukemia effects of Bidens pilosa
}

\author{
SHINJI NAKAMA ${ }^{1,2}$, CHIE ISHIKAWA $^{1,3}$, SAWAKO NAKACHI ${ }^{1,4}$ and NAOKI MORI ${ }^{1,5}$ \\ ${ }^{1}$ Department of Microbiology and Oncology, Graduate School of Medicine, University of the Ryukyus, \\ 207 Uehara, Nishihara, Okinawa 903-0215; ${ }^{2}$ Musashino Research Institute for Immunity, 790 Nishizatozoe, Gusukube, \\ Miyakojima, Okinawa 906-0106; ${ }^{3}$ Transdisciplinary Research Organization for Subtropics and Island Studies, \\ 1 Senbaru, Nishihara, Okinawa 903-0213; ${ }^{4}$ Department of Endocrinology, Metabolism and Hematology, \\ Graduate School of Medicine, University of the Ryukyus, 207 Uehara, Nishihara, Okinawa 903-0215, Japan
}

Received November 8, 2010; Accepted January 4, 2011

DOI: $10.3892 /$ ijo.2011.939

\begin{abstract}
We evaluated the effects of Bidens pilosa, a plant found in tropical and subtropical regions, and investigated the molecular pathways responsible for the anti-adult T-cell leukemia (ATL) effect. Water extracts of $B$. pilosa had growth suppressive effects on human T-cell leukemia virus type 1 (HTLV-1)-infected T-cell lines and ATL cells. B. pilosa extracts arrested cells in $\mathrm{G}_{1}$ cell cycle and induced apoptosis of HTLV-1-infected T-cell lines. B. pilosa extracts inhibited also the phosphorylation of I $\mathrm{B} B$ kinase $\beta$ and $\mathrm{I} \kappa \mathrm{B} \alpha$, and NF- $\kappa \mathrm{B}-\mathrm{DNA}$ binding, in conjunction with reduction of expression of proteins involved in $\mathrm{G}_{1} / \mathrm{S}$ cell cycle transition and suppression of apoptosis. Reactive oxygen species played a role in $B$. pilosa-mediated suppression of $\mathrm{NF}-\kappa \mathrm{B}$ activity. B. pilosa extracts also inhibited the expression of JunB and JunD, resulting in suppression of AP-1-DNA binding. In animals harboring tumors of HTLV-1-infected T-cell origin, treatment with $B$. pilosa extracts suppressed tumor growth. Our results suggest that $B$. pilos $a$ is a potentially useful medicinal plant for treatment of ATL.
\end{abstract}

\section{Introduction}

Human T-cell leukemia virus type 1 (HTLV-1) infection causes adult T-cell leukemia (ATL), a malignancy of peripheral $\mathrm{CD}^{+} \mathrm{T}$ cells (1-3). Despite the availability of various combination chemotherapy regimens, the median survival time of individuals with aggressive ATL such as acute and lymphoma types, is $<13$ months (4). This extremely grave outcome is mainly due to intrinsic resistance of leukemic cells to conventional or even high doses of chemotherapy and also to severe immunosuppression. Therefore, it is important to find

Correspondence to: Dr Naoki Mori, Present address: ${ }^{5}$ Department of Internal Medicine, Omoromachi Medical Center, 1-3-1 Uenoya, Naha, Okinawa 900-0011, Japan

E-mail: naokimori50@gmail.com

Key words: adult T-cell leukemia, human T-cell leukemia virus type $1, B$. pilosa, NF-кB, AP-1 appropriate therapeutic methods to prevent the development of ATL or to prolong survival after its occurrence. Three decades of research in this field has resulted in accumulation of a wealth of knowledge on the molecular pathways underlying the proliferation of ATL cells. Nuclear factor- $\kappa \mathrm{B}$ $(\mathrm{NF}-\kappa \mathrm{B})$ and activator protein 1 (AP-1) are induced by a unique HTLV-1 gene, Tax, and are related to proliferation of ATL cells (5). Therefore, targeting these molecules may provide a new approach to the treatment of ATL.

Researchers have been looking for anti-tumor agents in natural products to develop novel therapeutic agents for cancer. Herbal medicine has attracted a great deal of recent attention as an alternative cancer therapy because of its low toxicity and low cost. Bidens pilosa Linn. var. radiata is a tropical weed widely present in tropical and subtropical regions. This plant was originally found in tropical America and later introduced into the Pacific region and parts of Asia including Miyako Island, Okinawa, Japan. The whole plant or its aerial parts are used in various folk medicines and as a popular ingredient in herbal tea for its anti-inflammatory, anti-septic, liver-protective, blood-pressure lowering and hypoglycemic effects (6-10). Although diverse bioactivities have been identified in $B$. pilosa, its effect on human leukemia has not attracted attention so far. Ethyl caffeate isolated from $B$. pilosa has been reported to suppress NF- $\mathrm{B}$ activation and its downstream inflammatory mediators (11). With the objective of finding newer agents for the treatment of ATL, the present study was designed to investigate whether B. pilosa is a pharmacologically safe and effective inhibitor of cell growth of HTLV-1-infected T cells. We report here the anti-proliferative effects and molecular mechanisms of the apoptotic effects induced by B. pilosa in HTLV-1-infected T cells.

\section{Materials and methods}

Reagents. The B. pilosa powder produced from the aerial parts of B. pilosa Linn. var. radiata cultured on Miyako Island was provided by the Musashino Research Institute for Immunity (Tokyo, Japan). Antibodies to cyclin D2, c-IAP2, IкB $\alpha$, JunB and JunD, and NF- $\mathrm{BB}$ subunits p65, p50, c-Rel, p52 and RelB, and AP-1 subunits c-Fos, FosB, Fra-1, Fra-2, c-Jun, JunB and JunD for super shift assay were purchased from Santa Cruz 
Biotechnology (Santa Cruz, CA). Antibodies to Bax, Bcl-2, CDK4, CDK6, c-FLIP, p21, p53 and actin were purchased from NeoMarkers (Fremont, CA). Antibodies to XIAP and cyclin D1 were purchased from Medical and Biological Laboratories (Nagoya, Japan). Antibodies to IкB kinase (IKK) $\beta$, phospho-IKK $\beta$ (Ser181), phospho-IкB $\alpha$ (Ser32 and Ser36), cleaved caspase-3, cleaved caspase-8, cleaved caspase-9, cleaved poly(ADP-ribose) polymerase (PARP), survivin and $\mathrm{Bcl}-\mathrm{x}_{\mathrm{L}}$ were purchased from Cell Signaling Technology (Beverly, MA). Antibody to Tax, Lt-4, was described previously (12). $\mathrm{N}$-acetylcysteine (NAC) and caffeic acid were from Wako Pure Chemical Industries, Osaka, Japan.

Cells. The HTLV-1-infected T-cell lines, MT-2 (13), MT-4 (14), HUT-102 (1) and ED-40515(-) (15) were cultured in RPMI-1640 medium supplemented with $10 \%$ heat-inactivated fetal bovine serum. MT-2 and MT-4 are HTLV-1-transformed T-cell lines established by an in vitro coculture protocol. ED-40515(-) is a T-cell line of leukemic cell origin established from a patient with ATL. HUT-102 was also established from a patient with ATL and constitutively expresses viral genes, but its clonal origin is not clear. Peripheral blood mononuclear cells (PBMC) from healthy volunteers and patients with acute type ATL were also analyzed. Activated PBMC were grown in RPMI-1640 medium supplemented with phytohemagglutinin (PHA) $(10 \mu \mathrm{g} / \mathrm{ml})$ or interleukin-2 (IL-2) $(10 \mathrm{ng} / \mathrm{ml})$ for $48 \mathrm{~h}$. All samples were obtained after informed consent.

Cell viability and apoptosis assays. Cell lines $\left(1 \times 10^{5} / \mathrm{ml}\right)$ or PBMC $\left(1 \times 10^{6} / \mathrm{ml}\right)$ were cultured with various concentrations of B. pilosa in 96-well plates. After $24 \mathrm{~h}$, cell viability was evaluated by measuring the mitochondrial-dependent conversion of the water-soluble tetrazolium (WST)-8 (Nacalai Tesque, Kyoto, Japan) to a colored formazan product. Apoptotic events in cells were detected by staining with phycoerythrin-conjugated Apo2.7 monoclonal antibody (Beckman Coulter, Marseille, France) (16), and analyzed by flow cytometry (Epics XL, Beckman Coulter, Fullerton, CA).

Cell cycle analysis. Cell cycle analysis was performed with the CycleTest Plus DNA reagent kit (Becton-Dickinson Immunocytometry Systems, San Jose, CA). Cell suspensions were analyzed on a Coulter EPICS XL using EXPO32 software. The population of cells in each cell cycle phase was determined with the MultiCycle software.

In vitro measurement of caspase activity. Caspase activity was measured using the colorimetric caspase assay kits (Medical and Biological Laboratories). Cell extracts were recovered using the cell lysis buffer and assessed for caspase-3, -8 and -9 activities using colorimetric probes. The colorimetric caspase assay kits are based on detection of chromophore $\rho$-nitroanilide after cleavage from caspase-specific-labeled substrates. Colorimetric readings were performed in an automated microplate reader.

Measurement of intracellular ROS levels. Generation of reactive oxygen species (ROS) was measured by the total ROS detection kit (Enzo Life Sciences, Plymouth Meeting, PA). After treatment of cells with B. pilosa, HUT-102 cells were washed with wash buffer and then loaded for $30 \mathrm{~min}$ with $500 \mu 1$ of the ROS detection solution. The cells were then analyzed using a Coulter EPICS XL.

Western blot analysis. Cells were lysed in a buffer containing $62.5 \mathrm{mM}$ Tris- $\mathrm{HCl}$ (pH 6.8), $2 \%$ sodium dodecyl sulphate, $10 \%$ glycerol, $6 \%$ 2-mercaptoethanol and $0.01 \%$ bromophenol blue. Equal amounts of protein $(20 \mu \mathrm{g})$ were subjected to electrophoresis on sodium dodecyl sulphate-polyacrylamide gels followed by transfer to a polyvinylidene difluoride membrane and probing with the specific antibodies. The bands were visualized with the enhanced chemiluminescence kit (Amersham Biosciences, Piscataway, NJ).

Electrophoretic mobility shift assay (EMSA). Nuclear extracts were obtained as described by Antalis and Goldbolt (17) with modifications, and EMSA was performed as described previously (18). Briefly, $5 \mu \mathrm{g}$ of nuclearextract wasincubated with ${ }^{32} \mathrm{P}$-labeled probes. The DNA-protein complex was separated from the free oligonucleotides on a $4 \%$ polyacrylamide gel. The probes used were prepared by annealing the sense and antisense synthetic oligonucleotides; a typical NF- $\kappa \mathrm{B}$ element from the IL-2 receptor $\alpha$ chain (IL-2R $\alpha$ ) gene (5'-gatcCGGCAGGGGAATCTCCCTCTC-3') and an AP-1 element of the IL-8 gene (5'-gatcGTGATGACTCAGGTT-3'). The oligonucleotide 5'-gatcTGTCGAATGCAAATCACTA GAA-3', containing the consensus sequence of the octamer binding motif, was used to identify specific binding of the transcription factor Oct-1. This transcription factor regulates the transcription of a number of so-called housekeeping genes. The above underlined sequences represent the NF- $\mathrm{kB}, \mathrm{AP}-1$ or Oct-1 binding site.

Measurement of p19 antigen of HTLV-1. MT-2 cells were treated with B. pilosa $(500 \mu \mathrm{g} / \mathrm{ml})$ for $6 \mathrm{~h}$. Samples of the culture supernatant were collected and used to measure the p19 antigen of HTLV-1 (ZeptoMetrix, Buffalo, NY) by enzyme-linked immunosorbent assay.

In vivo therapeutic effect of B. pilosa. Five-week-old female C.B-17/Icr-scid mice were obtained from Ryukyu Biotec Co. (Urasoe, Japan). They were engrafted with $1 \times 10^{7}$ HUT-102 cells by subcutaneous injection in the postauricular region and then randomly placed into two groups of five mice each, one received vehicle only, while the other was treated with B. pilosa. Treatment was initiated on the next day of cell inoculation. B. pilosa was dissolved in distilled water at a concentration of $150 \mathrm{mg} / \mathrm{ml}$, and $3.75 \mathrm{~g} / \mathrm{kg}$ body weight of B. pilosa was administered by oral gavage every day for 28 days. Control mice received the same volume of the vehicle only for 28 days. Tumor size was monitored once a week. All mice were sacrificed on day 28 , and then the tumors were dissected out and their weight was measured. This study was performed according to the Guidelines for the Animal Experimentation of the University of the Ryukyus and was approved by the Animal Care and Use Committee of the University of the Ryukyus.

Statistical analysis. Data are expressed as the mean \pm SD. Differences between groups were assessed for statistical 

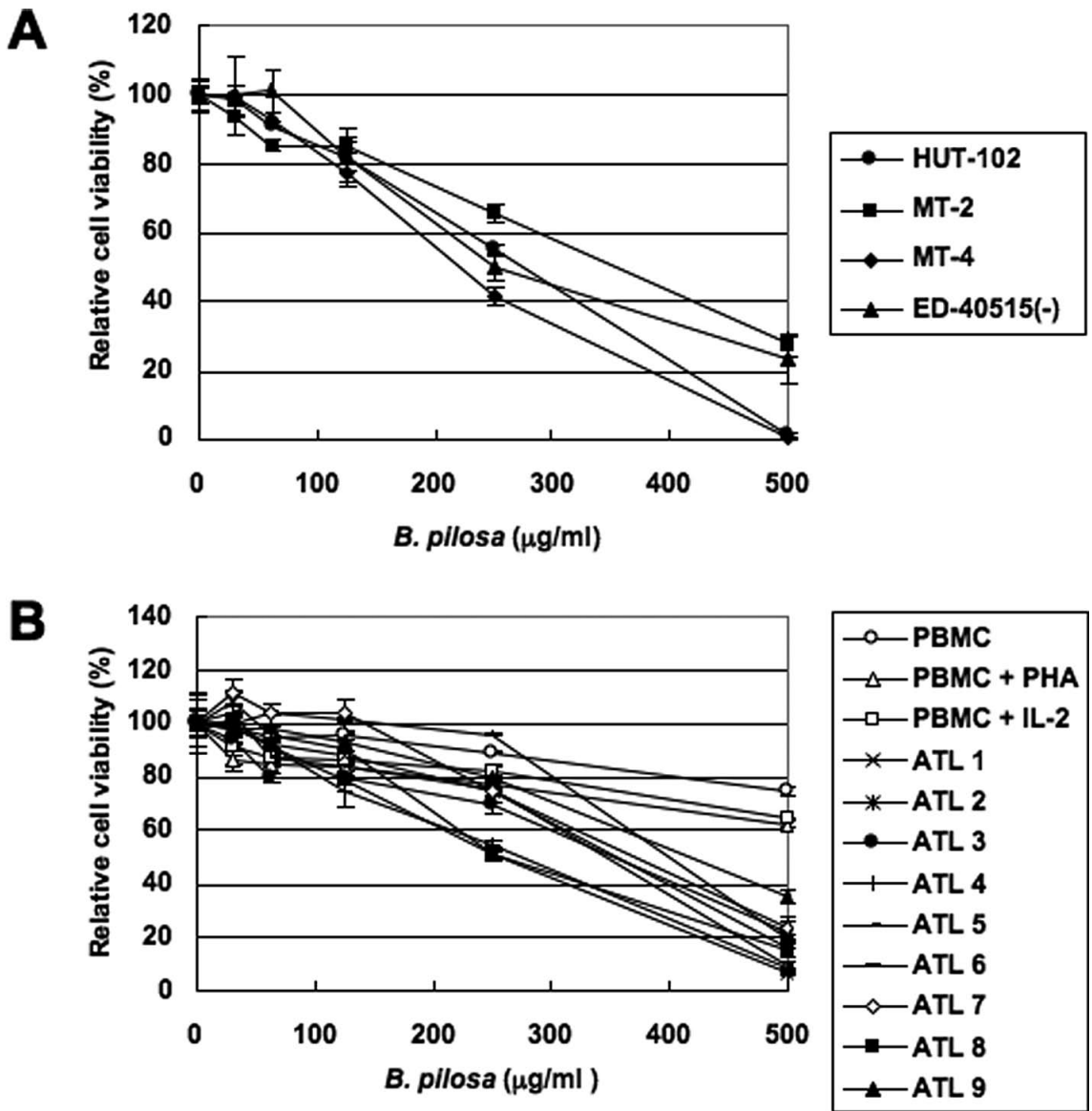

Figure 1. Water extracts of B. pilosa inhibit cell viability of HTLV-1-infected T-cell lines and PBMC from ATL patients. HTLV-1-infected T-cell lines (A), PBMC from ATL patients and a healthy control, and PHA- $(10 \mu \mathrm{g} / \mathrm{ml})$ or IL-2- $(10 \mathrm{ng} / \mathrm{ml})$ activated PBMC (B) were cultured with the indicated concentrations of B. pilosa for $24 \mathrm{~h}$, and cell viability was determined in triplicate cultures by WST- 8 assay. Data are mean \pm SD values expressed as percentage of the control.

significance by the Mann-Whitney U-test. $\mathrm{P}<0.05$ denoted the presence of a statistically significant difference.

\section{Results}

B. pilosa inhibits cell viability of HTLV-1-infected T-cell lines and primary ATL cells. First, we determined the effects of B. pilos $a$ on cell viability of HTLV-1-infected T-cell lines and primary ATL cells. Tax protein was detected by immunoblot analysis in the three HTLV-1-infected T-cell lines (MT-2, MT-4 and HUT-102) but not in the ATL-derived T-cell line [ED-40515(-)] (data not shown). Cell viability was assessed by the WST- 8 assay. Treatment with B. pilosa for $24 \mathrm{~h}$ resulted in a dose-dependent inhibition of cell viability of all tested HTLV-1-infected T-cell lines (Fig. 1A). The concentrations of $B$. pilosa required to inhibit cell viability of HTLV-1infected T-cell lines by $50 \%$ ( $\mathrm{IC}_{50}$ values) ranged from 220 to $355 \mu \mathrm{g} / \mathrm{ml}$. Importantly, resting and PHA- or IL-2-activated PBMC were resistant to $B$. pilosa, but activated PBMC were sensitive to $B$. pilosa compared with resting PBMC (Fig. 1B). We also examined the effects of B. pilosa on ATL cells freshly isolated from nine patients with the acute type ATL. ATL cells treated with B. pilosa showed reduced cell survival compared with resting and PHA- or IL-2-activated PBMC from normal healthy volunteers (Fig. 1B).
B. pilosa induces apoptosis of HTLV-1-infected T-cell lines. To investigate the mechanisms by which $B$. pilosa inhibited the cell viability of HTLV-1-infected T-cell lines, we analyzed apoptosis by immunostaining with Apo2.7, which specifically detects the $38-\mathrm{kDa}$ mitochondrial membrane antigen 7A6 expressed on the mitochondrial outer membrane during apoptosis (16). A significant increase in the proportion of cells positive for 7A6 was detected in all HTLV-1-infected T-cell lines after treatment with $B$. pilosa for $24 \mathrm{~h}$, and an increase in the apoptotic population was detected in HUT-102 cells in a B. pilosa dose-dependent manner (Fig. 2A).

B. pilosa-induced apoptosis is caspase-dependent. We then investigated the mechanism of the observed apoptosis. Cell extracts were obtained after various treatments and processed for Western blot analysis. Indeed, in HUT-102 and MT-2 cells, B. pilosa-induced apoptosis was associated with caspase activation, as shown by PARP cleavage (Fig. 2B). Furthermore, B. pilosa treatment resulted in cleavage of procaspase-3, -8 and -9. In addition, we assessed caspase-3, -8 and -9 activities using colorimetric probes. B. pilosa resulted in activation of caspases-3, -8 and -9 in HUT-102 cells (Fig. 2C). These results indicate that B. pilosa-induced apoptosis of HTLV-1-infected T-cell lines is mediated through caspase activation. 


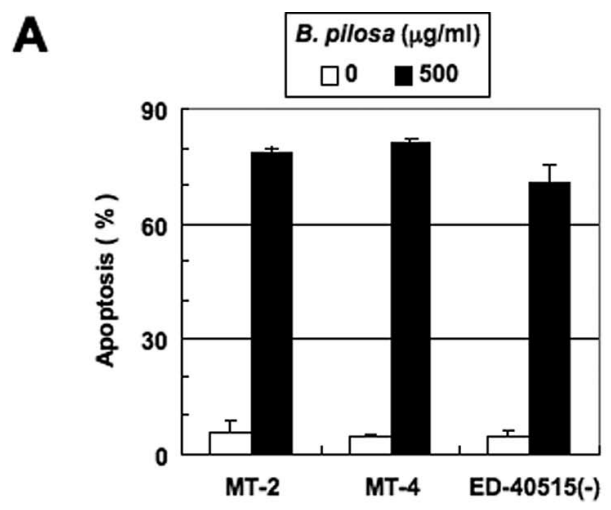

B

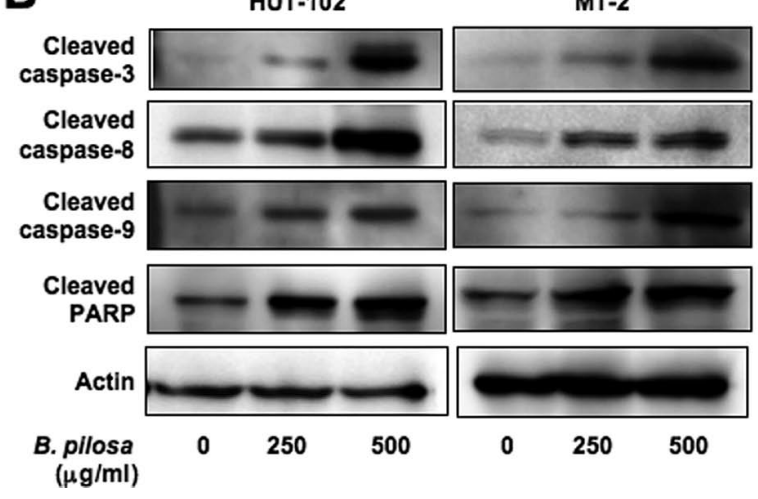

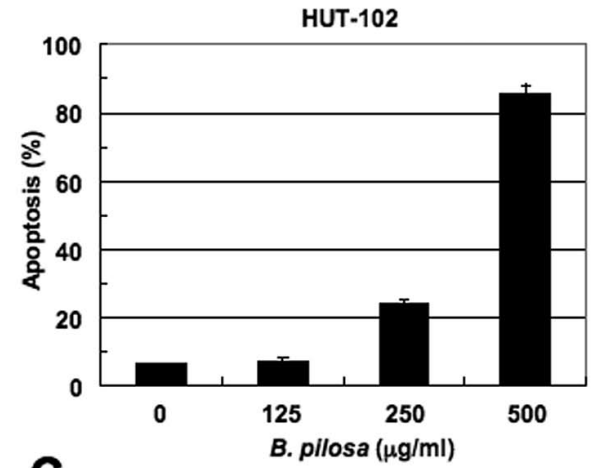
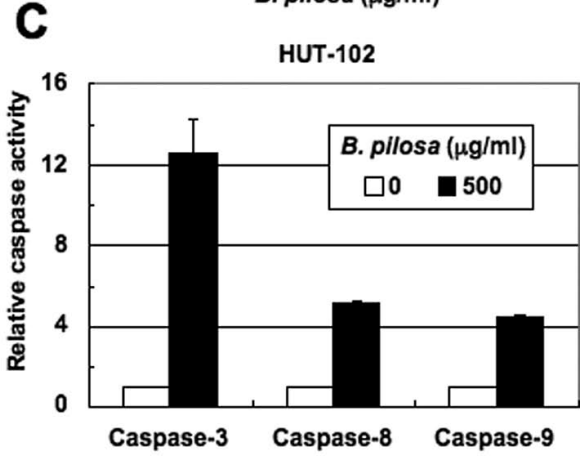

Figure 2. B. pilosa induces apoptosis of HTLV-1-infected T-cell lines. (A) HTLV-1-infected T-cell lines were cultured in the absence or presence of $B$. pilosa $(500 \mu \mathrm{g} / \mathrm{ml})$ (left panel). After $24 \mathrm{~h}$, Apo 2.7 staining was analyzed by flow cytometry. Data are the mean \pm SD percentages of apoptotic cells of both untreated (open bars) and B. pilosa-treated (solid bars) cells. HUT-102 cells were also incubated with various concentrations of $B$. pilosa for 24 h (right panel). The pro-apoptotic activity of $B$. pilos $a$ was assessed by Apo2.7 staining. Data are the mean \pm SD ( $=3$ ). (B) Cells were treated with the indicated concentrations of $B$. pilos $a$ for $24 \mathrm{~h}$ and subjected to immunoblot analyses with the indicated antibodies. (C) HUT-102 cells were treated with or without $B$. pilos $a$ ( $500 \mu \mathrm{g} / \mathrm{ml})$ for $24 \mathrm{~h}$. Caspase activity was assayed as described in Materials and methods and expressed relative to untreated cells, which were assigned a value of 1 . Values represent the mean $\pm \operatorname{SD}(n=3)$.

B. pilosa causes $G_{l}$ cell cycle arrest. We also examined the cellular DNA contents distribution by flow cytometric analysis on cell treatment. HUT-102 and MT-2 cells were incubated with $500 \mu \mathrm{g} / \mathrm{ml} \mathrm{B}$. pilosa for $24 \mathrm{~h}$ (Fig. 3A). Cultivation with B. pilosa for 6-12 $\mathrm{h}$ increased the population of the cells in the $\mathrm{G}_{1}$ phase, with a marked reduction of the cells in the $S$ phase, relative to untreated cells. This $\mathrm{G}_{1}$ cell cycle arrest was dosedependent (Fig. 3B). At $12 \mathrm{~h}$ after treatment, the percentage of HUT-102 cells in sub- $\mathrm{G}_{1}$ markedly increased from 4.1 in untreated cells to $52.6 \%$ (Fig. 3C), suggesting that cell cycle arrest is the cause of apoptosis. These results indicate that, together with induction of apoptosis, $B$. pilosa treatment induces a $\mathrm{G}_{1}$ cell cycle arrest in HTLV-1-infected T-cell lines, which likely contributes to the growth inhibitory effects.

Effects of B. pilosa on cell cycle and apoptosis regulatory proteins. To clarify the molecular mechanism of B. pilosa-induced inhibition of cell growth and apoptosis of HTLV-1-infected T-cell lines, we investigated the effect of B. pilosa on the expression of several intracellular regulators of cell cycle and apoptosis including cyclin D1, cyclin D2, CDK4, CDK6, p53, p21, Bcl-2, Bcl-x ${ }_{\mathrm{L}}$, c-IAP2, XIAP, survivin, Bax and c-FLIP by Western blot analysis. As shown in Fig. 4, B. pilosa did not alter CDK4 and p53 expression levels. In contrast, $B$. pilosa significantly decreased the expression of cyclin D1, cyclin D2, CDK6, Bcl-2, Bcl- $\mathrm{L}_{\mathrm{L}}$, c-IAP2,
XIAP, survivin and c-FLIP in HUT-102 and MT-2 cells in a dose-dependent manner. In addition, $B$. pilosa increased the expression of p21 and Bax. Comparable loading of protein was confirmed with a specific antibody for the housekeeping gene product actin (Fig. 4). Because cyclin D1, cyclin D2, CDK6, Bcl- $\mathrm{x}_{\mathrm{L}}$, c-IAP2, XIAP and c-FLIP are Tax-responsive genes (19-25), we also examined the expression level of Tax. B. pilosa did not change the Tax protein level in HUT-102 and MT-2 cells (Fig. 4A). These results indicate that the altered expression levels of cyclin D1, cyclin D2, CDK6, Bcl- $\mathrm{x}_{\mathrm{L}}$, c-IAP2, XIAP and c-FLIP proteins did not result from Tax down-regulation.

Inhibitory effects of $B$. pilosa on $N F-\kappa B$ activation. Several reports have suggested that $\mathrm{NF}-\kappa \mathrm{B}$ can prevent apoptosis and caspase activation as a survival factor and is required for the proliferation of various tumor cell types (26). Because NF- $\kappa \mathrm{B}$ is constitutively active in Tax-expressing and HTLV-1-infected T-cell lines as well as primary ATL cells (27), and Tax stimulates the expression of cyclin D2, CDK6, Bcl- $\mathrm{x}_{\mathrm{L}}, \mathrm{c}-\mathrm{IAP} 2$, XIAP and c-FLIP through the NF- $\kappa$ B pathway (20-25), we examined whether B. pilosa inhibits the NF-кB pathway. To study the DNA-binding activity of $\mathrm{NF}-\kappa \mathrm{B}$, we performed EMSA with radiolabeled double-stranded NF- $\kappa$ B oligonucleotides and nuclear extracts from untreated or B. pilosa-treated HTLV-1-infected T-cell lines. NF- $\kappa \mathrm{B}$ oligonucleotide probe 


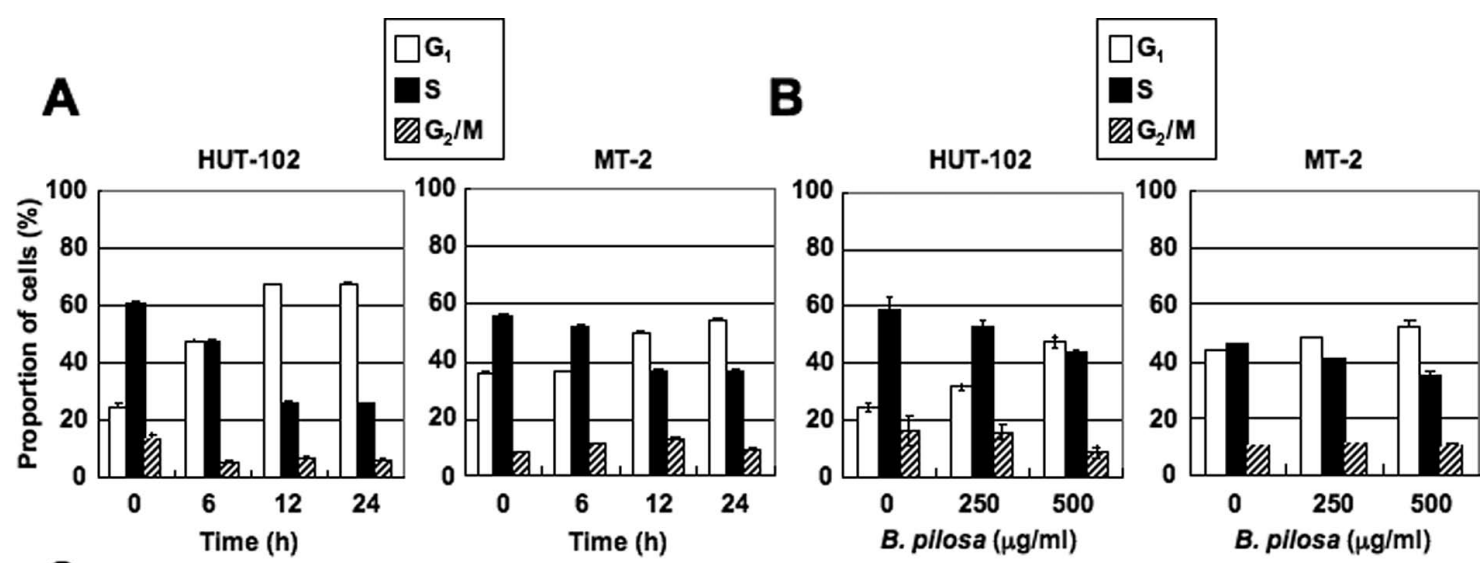

C

HUT-102
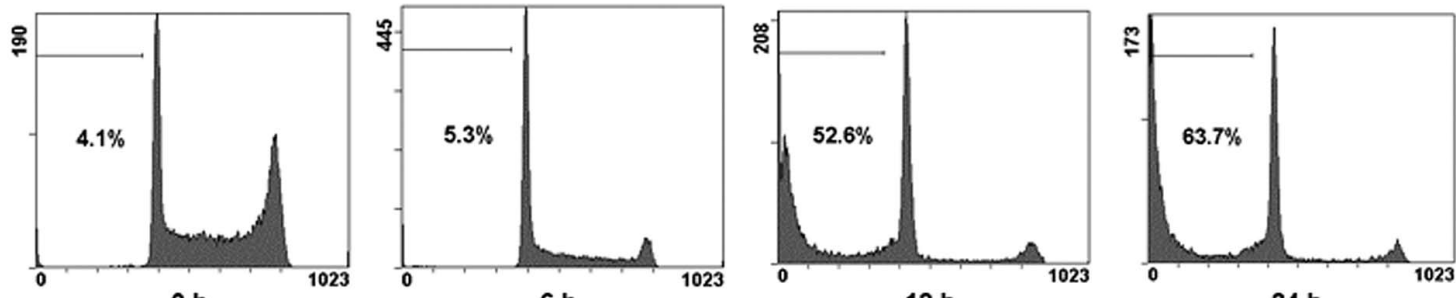

$12 \mathrm{~h}$

$24 \mathrm{~h}$

Figure 3. B. pilosa induces $\mathrm{G}_{1}$ cell cycle arrest in HTLV-1-infected T-cell lines. (A) HUT-102 and MT-2 cells were incubated with B.pilosa (500 $\left.\mu \mathrm{g} / \mathrm{ml}\right)$ for the indicated time periods. (B) HUT-102 and MT-2 cells were incubated with the indicated concentrations of $B$. pilos $a$ for 12 h. (C) HUT-102 cells were incubated with B. pilosa $(500 \mu \mathrm{g} / \mathrm{ml})$ for the indicated time periods. Cell cycle distribution was analyzed by flow cytometry by staining with propidium iodide. Data are the mean \pm SD percentages of cells at various phases of the cell cycle $(n=3)$.

A

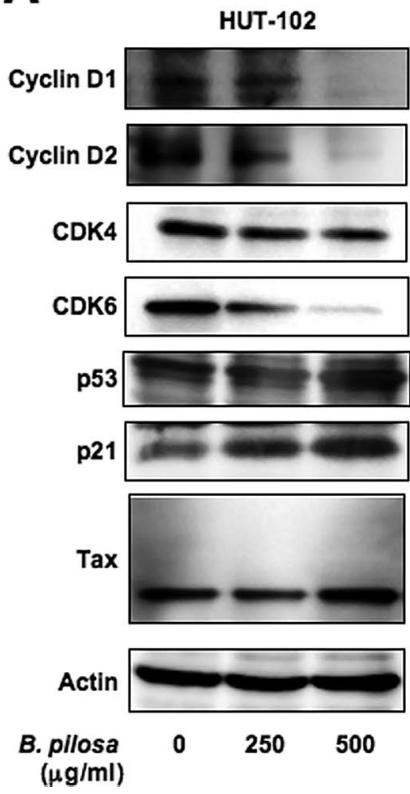

MT-2
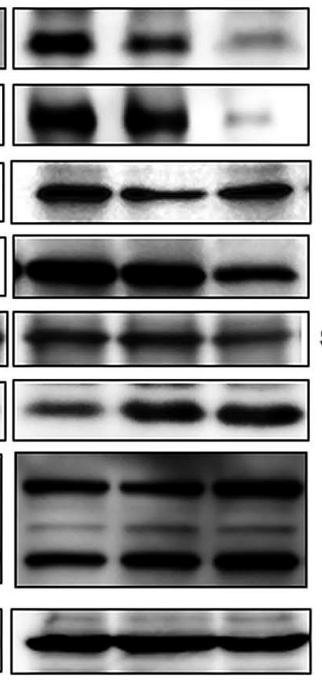

0
B

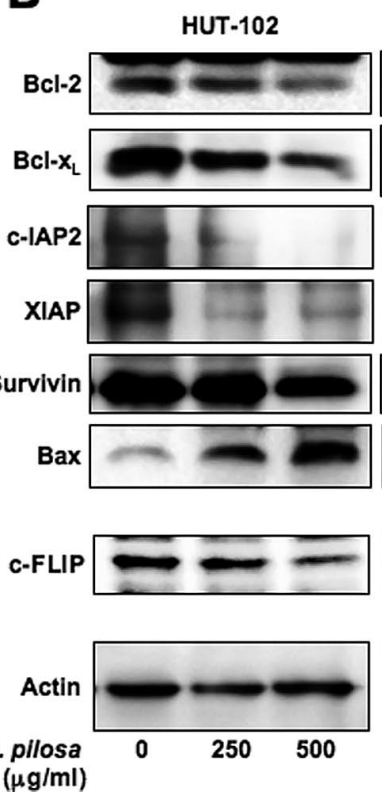

MT-2
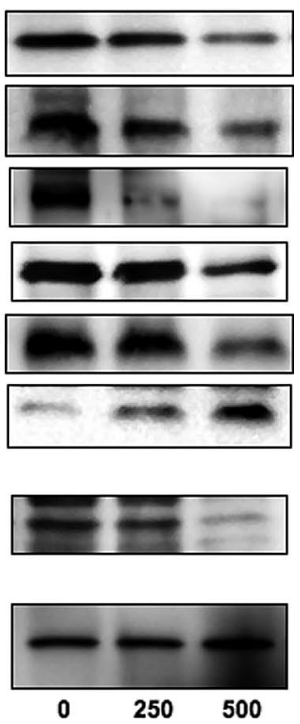

Figure 4. Effects of B. pilosa on the cell cycle and apoptosis regulatory proteins, and viral protein Tax. Cells were treated with various concentrations of B. pilosa for $24 \mathrm{~h}$. Whole cell extracts were prepared and immunoblotted with specific antibodies against cell cycle and Tax (A), and apoptosis regulatory proteins (B).

with nuclear extracts from untreated HTLV-1-infected T-cell lines generated DNA-protein gel shift complexes (Fig. 5A, left panels). These complexes were due to specific bindings of nuclear proteins to the NF- $\mathrm{kB}$ sequences because the binding activities diminished following the addition of cold probe but not by an irrespective sequence (Fig. 5A, left panels, lanes 2 and 3). We also showed that NF- $\mathrm{KB}$ complexes contain p50, p65, c-Rel and RelB in HUT-102, and p50, p65, 
A
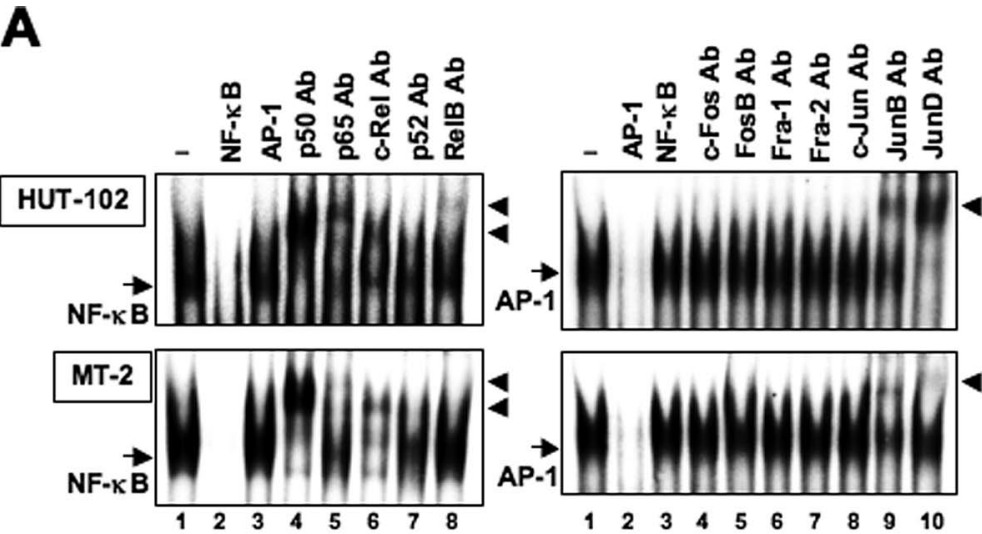

B

B

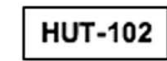

$N F \cdot K B$
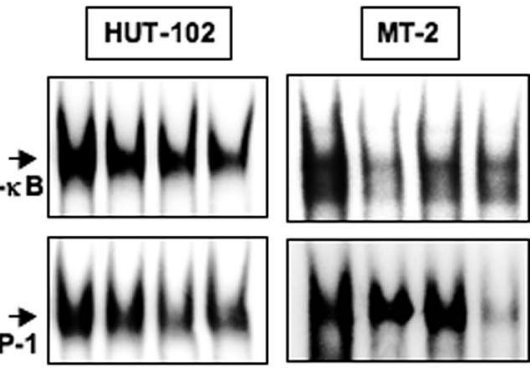

$\overrightarrow{A P-1}$
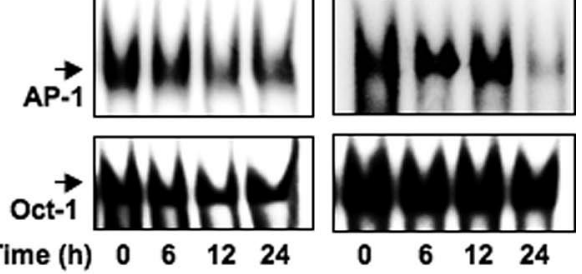

C
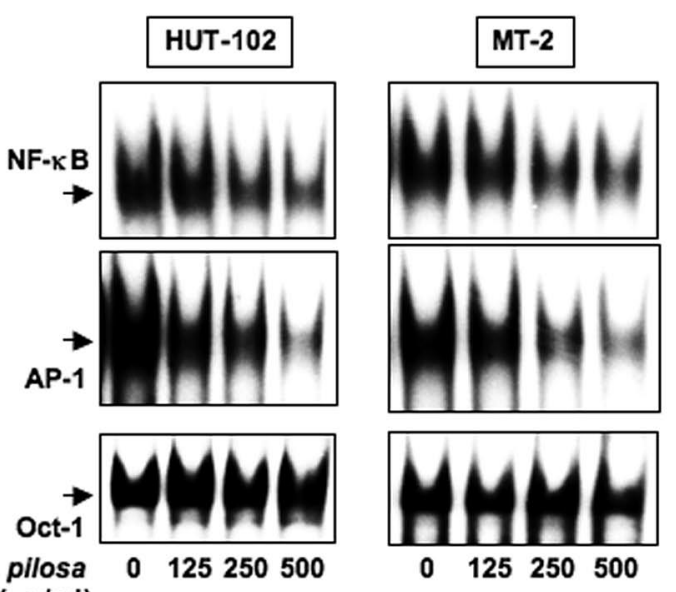
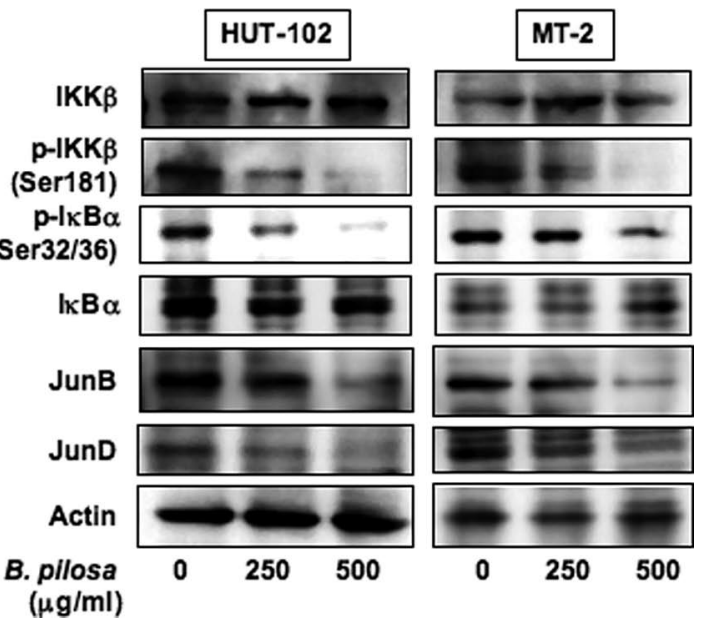

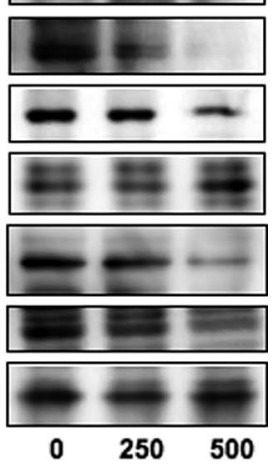

B. pllosa
$(\mu \mathrm{g} / \mathrm{ml})$

Figure 5. B. pilosa inhibits NF- $\mathrm{B}$ and AP-1 activities in HTLV-1-infected T-cell lines. (A) EMSA using untreated HUT-102 and MT-2 nuclear extracts and radiolabeled $\mathrm{NF}-\kappa \mathrm{B}$ and $\mathrm{AP}-1$ probes generated DNA-protein complexes, which were eliminated by 100 -fold molar excess of self-competitors but not by the same molar excess of the irrespective oligonucleotides. Supershift assays using the radiolabeled NF- $\mathrm{B}$ and AP-1 probes, untreated nuclear extracts, and the indicated antibodies (Ab) to NF- $\mathrm{KB}$ and AP-1 components. Arrows: the specific complexes, arrowheads: the DNA binding complexes supershifted by antibodies. (B and C) Effects of B. pilosa on activation of NF- $\mathrm{B}$, AP-1 and Oct-1 in HTLV-1-infected T-cell lines assessed by EMSA using oligonucleotide probes for NF- $\mathrm{B}$, AP-1 and Oct-1, respectively. Cells were treated with B. pilosa $(500 \mu \mathrm{g} / \mathrm{ml})$ for the indicated time periods (B) or with the indicated

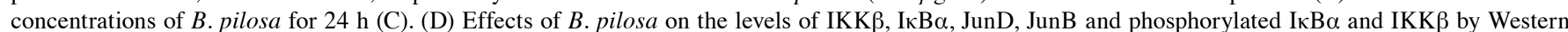
blot analysis. Cells were treated with various concentrations of $B$. pilosa for $24 \mathrm{~h}$, followed by protein extraction. Whole cell extracts of treated cells were immunoblotted with specific antibodies.

c-Rel and p52 in MT-2 cells (Fig. 5A, left panels, lanes 4-8). As shown in Fig. 5B and C, nuclear extracts prepared from HTLV-1-infected T-cell lines treated with $B$. pilosa exhibited a decrease in the intensity of the NF- $\mathrm{NB}$-containing gel shift complexes in a time- and dose-dependent manner, suggesting that $B$. pilosa down-regulates the DNA-binding activities of $\mathrm{NF}-\kappa \mathrm{B}$. Inhibition appeared specific to $\mathrm{NF}-\kappa \mathrm{B}$ and was not due to cell death because no significant change in binding activity of Oct-1 was observed after treatment of cells with B. pilosa (Fig. 5B and C).

Degradation of $\mathrm{I} \kappa \mathrm{B} \alpha$ and subsequent release of $\mathrm{NF}-\kappa \mathrm{B}$ require prior phosphorylation at Ser32 and Ser36 residues (28). To investigate whether the inhibitory effects of $B$. pilosa are mediated through alteration of phosphorylation of $\mathrm{I} \kappa \mathrm{B} \alpha$, HUT-102 and MT-2 cells were treated with B. pilos $a$ and their protein extracts were checked for phospho-I $\mathrm{B} \alpha \alpha$ expression. Untreated cells constitutively expressed Ser32- and Ser36phosphorylated I $\kappa \mathrm{B} \alpha$ (Fig. 5D), while B. pilosa decreased the phosphorylated I $\kappa \mathrm{B} \alpha$ in a dose-dependent manner, suggesting that $B$. pilosa inhibited phosphorylation of $\mathrm{I} \kappa \mathrm{B} \alpha$. IKK is part of a multiprotein complex that contains IKK $\alpha$ and IKK $\beta$ subunits, and $\mathrm{IKK} \beta$ is critical in mediating I $\mathrm{I} \mathrm{B} \alpha$ phosphorylation (28). Active IKK $\beta$ is phosphorylated on two Ser177 and Ser181, within the activation loop of the kinase domain. B. pilosa suppressed IKK $\beta$ phosphorylation in a dose-dependent manner, suggesting that $B$. pilosa suppresses $N F-\kappa B$ activation by inhibiting IKK $\beta$ activity (Fig. 5D).

ROS play a role in B. pilosa-mediated growth inhibition and $N F-\kappa B$ suppression. The protein extract of Bidens alba, a Bidens spp. plant, has been reported to induce apoptosis related to the production of ROS in human colon cancer (29). In addition, ROS play a role in suppression of $N F-\kappa B$ activity (30). We measured the capacity of $B$. pilosa to cause intracellular oxidation in HTLV-1-infected T cells. When HUT-102 cells were treated with $B$. pilosa, intracellular ROS concentration was increased within 15 min as observed in Fig. 6A. NAC is a widely used thiol-containing anti-oxidant that scavenges ROS in cells by interacting with $\mathrm{OH}$ and $\mathrm{H}_{2} \mathrm{O}_{2}$, thus affecting ROS-mediated signaling pathways. To address whether ROS plays a role in $B$. pilosa-induced inhibition of cell viability, we pretreated HUT-102 cells with NAC for $2 \mathrm{~h}$ then with 
A

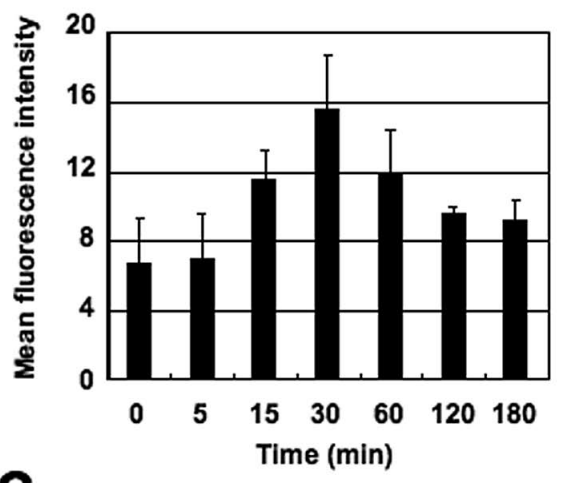

C
B

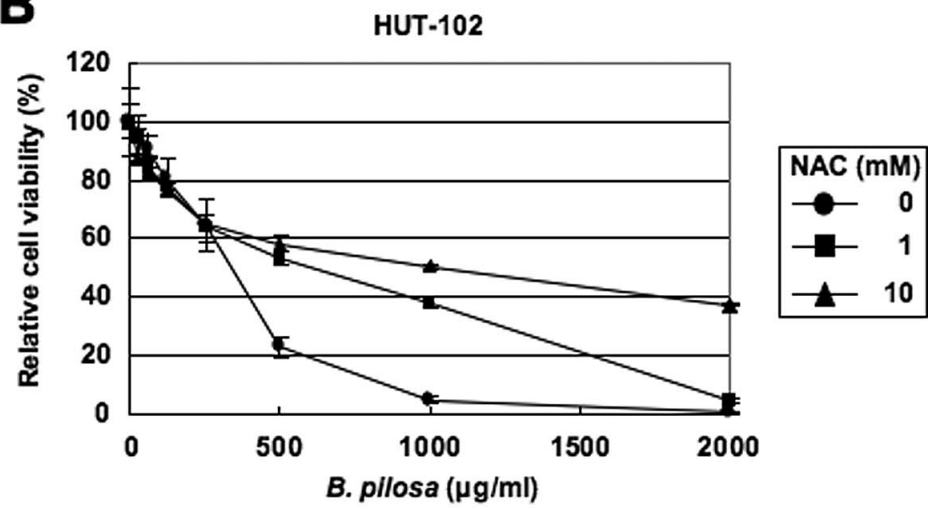

NAC (mM)

0

HUT-102

1

10
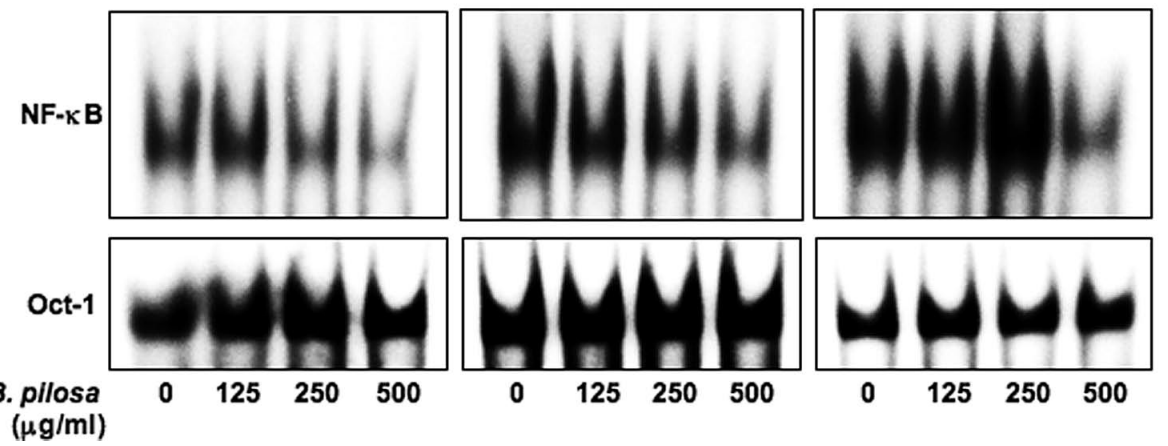

Figure 6. NAC attenuated B. pilosa-induced suppression of cell viability and constitutively active NF- $\mathrm{B}$. (A) Effect of $B$. pilos $a$ treatment on ROS generation. Intracellular ROS concentration was determined by treating HUT-102 cells with $\mathrm{B}$. pilosa (500 $\mu \mathrm{g} / \mathrm{ml})$ for 5-180 min, the cells were loaded with total ROS detection reagent, and the fluorescence was measured by flow cytometry. (B and C) HUT-102 cells were preincubated with 1 or 10 mM NAC for $2 \mathrm{~h}$ before exposure to various concentrations of $B$. pilosa for $24 \mathrm{~h}$. (B) Cell viability was determined in triplicate cultures by WST- 8 assay. Data are the mean \pm SD values expressed as percentage of the control. (C) Nuclear extracts were prepared and EMSA was performed using oligonucleotide probes for NF- $\kappa \mathrm{B}$ and Oct-1, respectively.

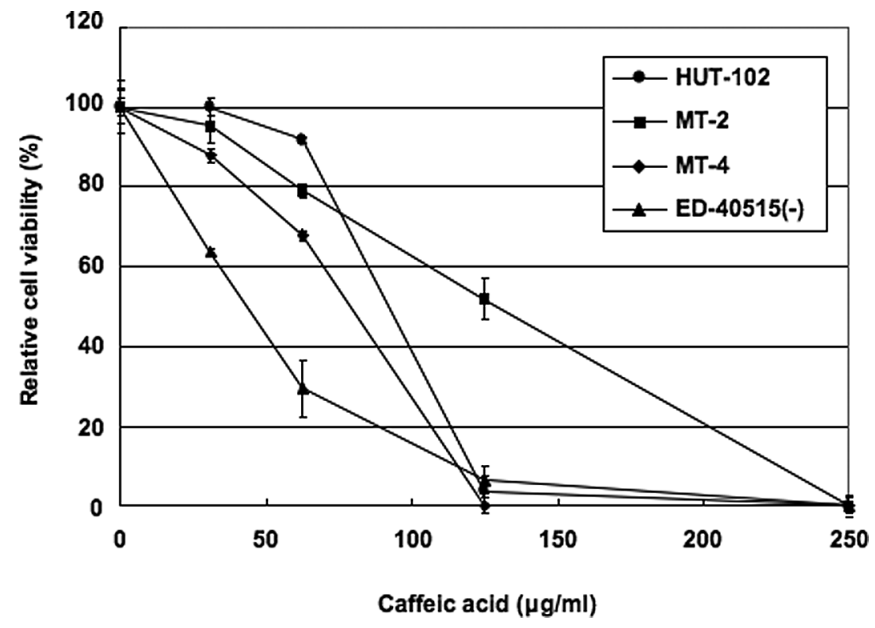

Figure 7. Effects of caffeic acid on the viability of HTLV-1-infected T-cell lines. Cells were incubated with various concentrations of caffeic acid for $24 \mathrm{~h}$, and cell growth was determined in triplicate cultures by WST-8 assay. Data are the mean \pm SD values expressed as percentage of the control.

B. pilosa for $24 \mathrm{~h}$. As shown in Fig. 6B, pretreatment with NAC partially suppressed $B$. pilosa-induced inhibition of cell viability in a dose-dependent manner, suggesting that
B. pilosa-induced inhibition of cell viability is in part mediated by ROS. We next sought to determine whether ROS inhibit the NF- $\kappa \mathrm{B}$ activity in HTLV-1-infected T-cell lines. HUT-102 cells were pretreated with NAC and subsequently treated with $B$. pilosa. EMSA showed that pretreatment of cells with NAC partially suppressed $B$. pilos $a$-induced inhibition of active NF- $\mathrm{KB}$ (Fig. $6 \mathrm{C}$ ), suggesting that ROS play a role in B. pilosa-mediated suppression of $\mathrm{NF}-\kappa \mathrm{B}$ activity.

Inhibitory effects of B. pilosa on AP-1 activation. AP-1 is also a crucial mediator of both cell cycle promoting and cell-death inhibiting pathways in HTLV-1-infected T cells (31). Therefore, we examined the effect of B. pilosa treatment on AP-1. High constitutive AP-1 DNA-binding activities were detected in HUT-102 and MT-2 cells (Fig. 5A, right panels). Supershift analysis with antibodies indicated that the AP-1 complex in both cell lines contained JunB and JunD. As shown in Fig. 5B and C, AP-1 DNA-binding activity diminished in the presence of $B$. pilosa in a time- and dose-dependent manner. In addition, $B$. pilosa also dose-dependently decreased the expression of JunB and JunD (Fig. 5D). These findings suggest that $B$. pilosa depletes JunB and JunD, resulting in inactivation of AP-1.

Inhibition of viral production. MT-2 cells normally produce infectious HTLV-1 virions that could be detected in the super- 
A

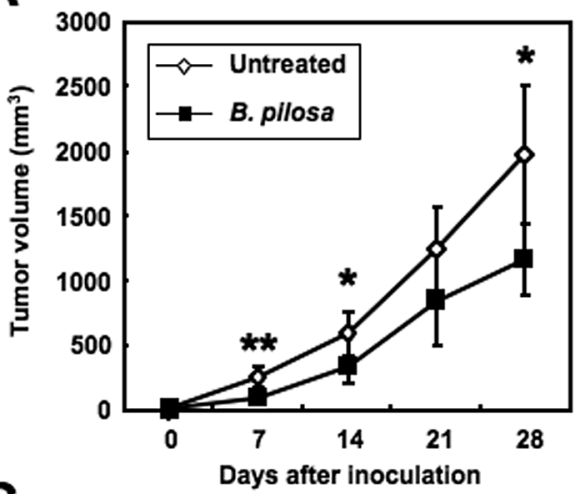

C

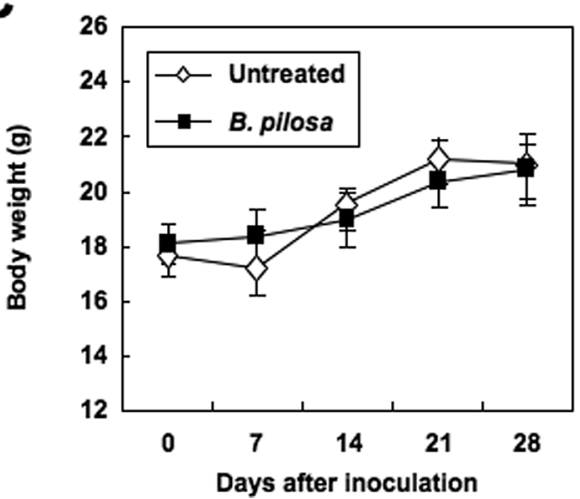

B

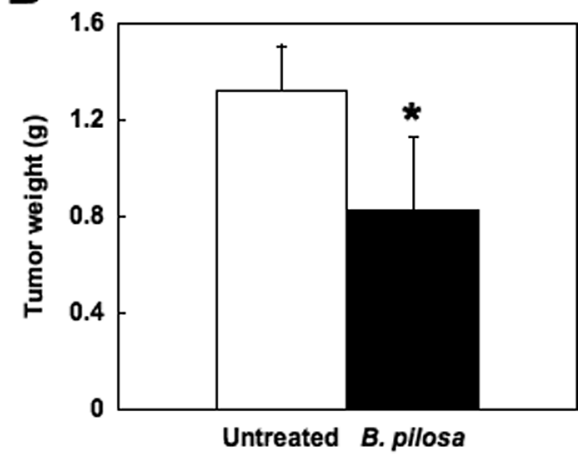

Figure 8. Inhibition of growth of HUT-102 cells in SCID mice. (A) Growth of the tumors after inoculation of HUT-102 cells subcutaneously. Note the growthsuppressive effect of $B$. pilosa. (B) Weight of tumors removed from B. pilosa-treated mice and untreated mice on day 28 after cell inoculation. (C) Body weight of mice measured weekly for four weeks. Data are the mean $\pm \mathrm{SD}$ of five mice in each group. ${ }^{*} \mathrm{P}<0.05,{ }^{* *} \mathrm{P}<0.01$, compared with the control.

natant using p19 gag enzyme-linked immunosorbent assay. We therefore treated MT-2 cells with B. pilosa $(500 \mu \mathrm{g} / \mathrm{ml})$ for $6 \mathrm{~h}$. Compared to untreated cells $(1000 \mathrm{pg} / \mathrm{ml})$, B. pilosa treatment reduced p19 levels $(687 \mathrm{pg} / \mathrm{ml})$. These results imply that short-time incubation of $B$. pilosa that does not cause cell death effectively inhibits viral production.

Inhibition of cell viability induced by caffeic acid. Six caffeic acid derivatives (neochlorogenic acid, chlorogenic acid, 4-O-caffeoylquinic acid, 3,4-di- $O$-caffeoylquinic acid, 3,5-di- $O$-caffeoylquinic acid and 4,5-di- $O$-caffeoylquinic acid) and 7 flavonoids (rutin, quercetin, quercetin derivative, hyperin, isoquercitrin, centaurein and jacein) have been isolated from $B$. pilos $a$ (32). To determine the role of the active compounds on $B$. pilosa-induced cytotoxicity, we examined the effect of caffeic acid on the viability of HTLV-1-infected T-cells. Caffeic acid suppressed cell viability in a dosedependent manner (Fig. 7).

In vivo effects of B. pilosa in SCID mice inoculated with HTLV-1-infected T-cells. Because the B. pilosa-induced inhibition of ATL cell viability suggests that this compound is a potentially effective agent in the treatment of ATL, we examined the in vivo effects of B. pilosa in a SCID mouse model. After 28-day treatment, the mean tumor volume (Fig. 8A) and weight (Fig. 8B) were significantly lower than those of vehicle-treated mice. There was no significant difference in body weight gain during the period from day 0 to day
28 between the vehicle and B. pilosa-treated groups (Fig. 8C). During this period, mice treated with $B$. pilosa appeared generally healthy. These results suggest that $B$. pilosa also has in vivo anti-ATL effect.

\section{Discussion}

Several constituents of $B$. pilosa have a variety of clinical effects, but whether it has anti-leukemia effect remains to be determined. In the present study, we investigated the anti-ATL effect of extracts of B. pilosa. Our data indicated that B. pilosa is cytotoxic against all tested HTLV-1-transformed and ATL-derived T-cell lines as well as primary ATL cells. This cytotoxic effect appears to be HTLV-1-infected T-cell-specific, because $B$. pilosa had negligible effect on normal resting and activated PBMC.

How does $B$. pilosa induce inhibition of cell growth? Two mechanisms are proposed here: i) B. pilosa had an impact on cell cycle phase. In the present study, flow cytometry of HUT-102 and MT-2 cells treated with B. pilosa indicated the accumulation of cells at the $\mathrm{G}_{1}$ peak, and reduction of cells in the $\mathrm{S}$ phase. Therefore, it is conceivable that $B$. pilosa inhibited the proliferation of HTLV-1-infected T-cell lines by arresting cell cycle; ii) B. pilosa induced apoptosis of HTLV-1-infected T-cell lines. Apo2.7 staining confirmed that B.pilosa induced apoptosis of HTLV-1-infected T-cell lines.

Targeting the key regulators of the $\mathrm{G}_{1} / \mathrm{S}$ transition such as cyclins, CDKs and CDK inhibitors may be one of the mecha- 


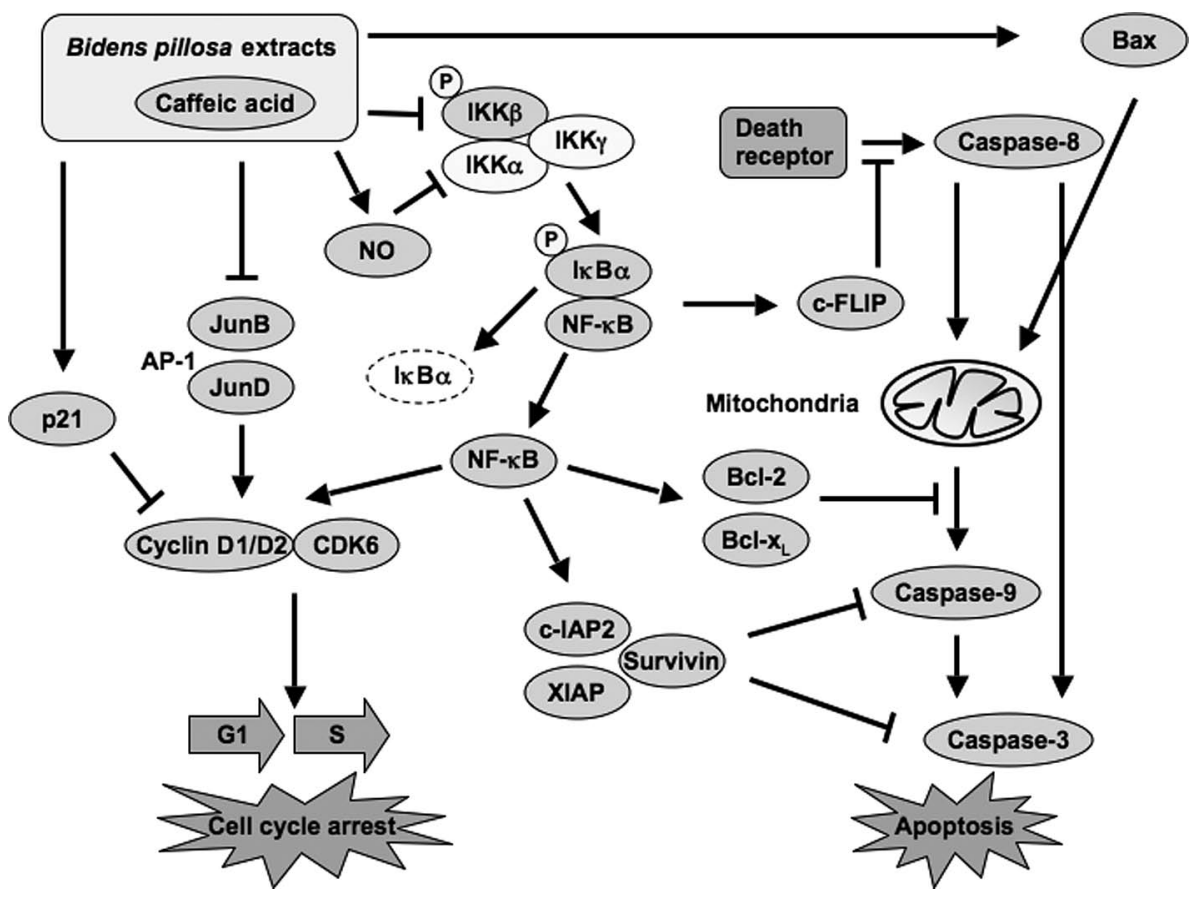

Figure 9. The proposed model to delineate the actions of B. pilosa.

nisms by which $B$. pilosa induces cell cycle arrest. We found that cyclin D1, cyclin D2 and CDK6 are down-regulated and p21 is up-regulated in a p53-independent manner in parallel with cell cycle $\mathrm{G}_{1}$ arrest in HTLV-1-infected T-cell lines exposed to B. pilosa (Fig. 9).

Analysis of the apoptotic pathway revealed activation of both membrane and mitochondrial pathways, as evidenced by detection of cleaved products and activation of caspase- 8 and -9 . B. pilosa down-regulated the expression of the anti-apoptotic proteins, Bcl-2, Bcl- $\mathrm{L}_{\mathrm{L}}$, c-IAP2, XIAP and survivin. $\mathrm{Bcl}-2$ and $\mathrm{Bcl}-\mathrm{x}_{\mathrm{L}}$ are the principal regulators of the mitochondrial-dependent pathway for apoptosis (33), and their down-regulation is involved in caspase-9-dependent apoptosis. Because c-IAP2, XIAP and survivin are associated with caspase- 3 and caspase-9, and inhibit their activities $(34,35)$, it appears that B. pilosa stimulates caspase-3- and caspase-9-dependent apoptosis by down-regulating the expression of these IAP family proteins. The anti-apoptotic protein c-FLIP suppresses the activation of caspase-8 (36). Decrease in expression of c-FLIP may be responsible for the B. pilos $a$-induced caspase- 8 activation. On the other hand, the pro-apoptotic protein Bax was up-regulated by $B$. pilos $a$ treatment, suggesting that Bax also plays a role in B. pilosainduced apoptosis (Fig. 9).

$\mathrm{NF}-\kappa \mathrm{B}$ is a transcription factor that plays crucial roles in cell proliferation and apoptosis (26). Many studies have suggested that NF- $\kappa \mathrm{B}$-mediated cell proliferation and survival may be closely related to its downstream genes involved in the cell cycle machinery and suppression of apoptosis (26). In HTLV-1-infected T cells, NF- $\kappa \mathrm{B}$ activation serves as a proliferative and survival signal (5). Our studies indicate that treatment with $B$. pilosa inhibited activation of $\mathrm{NF}-\kappa \mathrm{B}$ as indicated by EMSA. We confirmed that the inhibitory action of B. pilosa was based on its effect on phosphorylation of
IKK $\beta$ and IкB $\alpha$. Treatment of HTLV-1-infected T-cell lines with $B$. pilosa down-regulated the expression of cyclin D2, CDK6, Bcl- $\mathrm{x}_{\mathrm{L}}$, c-IAP2, XIAP, survivin and c-FLIP genes regulated by NF- $\mathrm{B}$ (20-25,37) (Fig. 9).

Our results also showed that abrogation of ROS by NAC partially prevented $B$. pilosa-induced events in the $\mathrm{NF}-\kappa \mathrm{B}$ pathway. Furthermore, a scavenger of ROS attenuated B. pilosa-mediated cytotoxicity. Therefore, accumulation of ROS partially contributed to the cytotoxicity of $B$. pilosa and may be a mechanism parallel to NF- $\kappa \mathrm{B}$ inhibition. However, NAC could not completely block the $B$. pilos $a$-induced cytotoxicity and $\mathrm{NF}-\kappa \mathrm{B}$ inhibition, implying that some other pathways are involved in the $B$. pilosa protein-extract treatment (Fig. 9).

AP-1 is also known to regulate cell proliferation (38), and required for proliferation of HTLV-1-infected T cells (31). Our results also showed that B. pilosa inhibited JunB and JunD expression, resulting in the suppression of AP-1 DNA-binding in HTLV-1-infected T-cell lines. AP-1 regulates the expression and function of cell cycle regulators such as cyclin D1 (39). In addition, the cyclin D2 promoter contains NF- $\kappa \mathrm{B}$ and AP-1 sites (40). JunB is also controlled by NF- $\kappa B$ (41). It is therefore likely that $\mathrm{NF}-\kappa \mathrm{B}$ and $\mathrm{AP}-1$, in concert, support the proliferation of HTLV-1-infected T cells by activating cyclin D1 and cyclin D2. We speculate that B. pilosa inhibits the expression of cyclin D1 and cyclin D2 through the suppression of both NF- $\kappa$ B and AP-1, resulting in the induction of $\mathrm{G}_{1}$ cell cycle arrest (Fig. 9).

We performed experiments in MT-2 cells that can produce viruses (13). Interestingly, B. pilosa inhibited viral production without having any toxic effects. Thus, $B$. pilosa seems to be a viable option in inhibiting infection. Our results showed that the active compound in B. pilosa, caffeic acid, suppressed cell viability in HTLV-1-infected T-cell lines. Although the $\mathrm{IC}_{50}$ 
values for caffeic acid and $B$. pilosa against HTLV-1-infected T-cell lines were found to range from 44 to $131 \mu \mathrm{g} / \mathrm{ml}$ and from 220 to $355 \mu \mathrm{g} / \mathrm{ml}$, respectively, the content of caffeic acid was $12 \mathrm{mg} / \mathrm{g}$ of extract. Therefore, the roles of the synergistic activities of caffeic acid and other compounds in the cytotoxic activity of $B$. pilosa remain to be investigated.

Notably, $B$. pilosa showed potent anti-ATL activity against xenografted tumors in SCID mice. Ex vivo treatment with $B$. pilosa was effective against primary ATL cells. Our report is the first to show that B. pilosa is effective both in vitro and in vivo against ATL cells. The cytotoxic effects of $B$. pilos $a$ on ATL cells in conjunction with its minimal cytotoxicity against normal cells could make it a potentially chemopreventive and/ or therapeutic agent for the treatment of ATL.

\section{Acknowledgements}

We acknowledge Drs Taeko Okudaira, Jun-nosuke Uchihara, Naoya Taira and Kazuiku Ohshiro for providing patient samples; and Dr Yuetsu Tanaka for providing Tax antibody. We also thank the Fujisaki Cell Center Hayashibara Biochemical Laboratories for providing HUT-102; and Dr Michiyuki Maeda for providing ED-40515(-) cell line. Recombinant human IL-2 was kindly provided by Takeda Chemical Industries (Osaka, Japan).

\section{References}

1. Poiesz BJ, Ruscetti FW, Gazdar AF, Bunn PA, Minna JD and Gallo RC: Detection and isolation of type $\mathrm{C}$ retrovirus particles from fresh and cultured lymphocytes of a patient with cutaneous T-cell lymphoma. Proc Natl Acad Sci USA 77: 7415-7419, 1980.

2. Hinuma Y, Nagata K, Hanaoka M, Nakai M, Matsumoto T, Kinoshita KI, Shirakawa S and Miyoshi I: Adult T-cell leukemia: antigen in an ATL cell line and detection of antibodies to the antigen in human sera. Proc Natl Acad Sci USA 78: 6476-6480, 1981.

3. Yoshida M, Miyoshi I and Hinuma Y: Isolation and characterization of retrovirus from cell lines of human adult T-cell leukemia and its implication in the disease. Proc Natl Acad Sci USA 79: 2031-2035, 1982

4. Yamada Y, Tomonaga M, Fukuda H, Hanada S, Utsunomiya A, Tara M, Sano M, Ikeda S, Takatsuki K, Kozuru M, Araki K, Kawano F, Niimi M, Tobinai K, Hotta T and Shimoyama M: A new G-CSF-supported combination chemotherapy, LSG15, for adult T-cell leukaemia-lymphoma: Japan Clinical Oncology Group Study 9303. Br J Haematol 113: 375-382, 2001.

5. Mori N: Cell signaling modifiers for molecular targeted therapy in ATLL. Front Biosci 14: 1479-1489, 2009.

6. Geissberger P and Séquin U: Constituents of Bidens pilosa L.: do the components found so far explain the use of this plant in traditional medicine? Acta Trop 48: 251-261, 1991.

7. Chin H-W, Lin C-C and Tang K-S: The hepatoprotective effects of Taiwan folk medicine ham-hong-chho in rats. Am J Chin Med 24: 231-240, 1996.

8. Pereira RL, Ibrahim T, Lucchetti L, da Silva AJ and Goncalves de Moraes VL: Immunosuppressive and anti-inflammatory effects of methanolic extract and the polyacetylene isolated from Bidens pilosa L. Immunopharmacology 43: 31-37, 1999.

9. Dimo T, Rakotonirina SV, Tan PV, Azay J, Dongo E and Cros G: Leaf methanol extract of Bidens pilosa prevents and attenuates the hypertension induced by high-fructose diet in Wistar rats. J Ethnopharmacol 83: 183-191, 2002.

10. Ubillas RP, Mendez CD, Jolad SD, Luo J, King SR, Carlson TJ and Fort DM: Antihyperglycemic acetylenic glucosides from Bidens pilosa. Planta Med 66: 82-83, 2000.

11. Chiang Y-M, Lo C-P, Chen Y-P, Wang S-Y, Yang N-S, Kuo Y-H and Shyur L-F: Ethyl caffeate suppresses NF- $\kappa$ B activation and its downstream inflammatory mediators, iNOS, COX-2, and $\mathrm{PGE}_{2}$ in vitro or in mouse skin. Br J Pharmacol 146: 352-363, 2005.
12. Tanaka Y, Yoshida A, Takayama Y, Tsujimoto H, Tsujimoto A, Hayami $M$ and Tozawa H: Heterogeneity of antigen molecules recognized by anti-tax1 monoclonal antibody Lt-4 in cell lines bearing human $\mathrm{T}$ cell leukemia virus type I and related retroviruses. Jpn J Cancer Res 81: 225-231, 1990.

13. Miyoshi I, Kubonishi I, Yoshimoto S, Akagi T, Ohtsuki Y, Shiraishi Y, Nagata $\mathrm{K}$ and Hinuma Y: Type C virus particles in a cord T-cell line derived by co-cultivating normal human cord leukocytes and human leukaemic T cells. Nature 294: 770-771, 1981.

14. Yamamoto N, Okada M, Koyanagi Y, Kannagi M and Hinuma Y: Transformation of human leukocytes by cocultivation with an adult $\mathrm{T}$ cell leukemia virus producer cell line. Science 217: 737-739, 1982.

15. Maeda M, Shimizu A, Ikuta K, Okamoto H, Kashihara M, Uchiyama T, Honjo $\mathrm{T}$ and Yodoi J: Origin of human T-lymphotrophic virus I-positive $\mathrm{T}$ cell lines in adult $\mathrm{T}$ cell leukemia. Analysis of T cell receptor gene rearrangement. J Exp Med 162: 2169-2174, 1985.

16. Zhang C, Ao Z, Seth A and Schlossman SF: A mitochondrial membrane protein defined by a novel monoclonal antibody is preferentially detected in apoptotic cells. J Immunol 157: 3980-3987, 1996

17. Antalis TM and Goldbolt D: Isolation nuclei from hematopoietic cell types. Nucleic Acids Res 19: 4301, 1991.

18. Mori N and Prager D: Transactivation of the interleukin-1 $\alpha$ promoter by human T-cell leukemia virus type I and type II Tax proteins. Blood 87: 3410-3417, 1996.

19. Kim Y-M, Geiger TR, Egan DI, Sharma N and Nyborg JK: The HTLV-1 tax protein cooperates with phosphorylated CREB, TORC2 and p300 to activate CRE-dependent cyclin D1 transcription. Oncogene 29: 2142-2152, 2010.

20. Huang Y, Ohtani K, Iwanaga R, Matsumura Y and Nakamura M: Direct trans-activation of the human cyclin D2 gene by the oncogene product Tax of human T-cell leukemia virus type I. Oncogene 20: 1094-1102, 2001.

21. Iwanaga R, Ohtani K, Hayashi T and Nakamura M: Molecular mechanism of cell cycle progression induced by the oncogene product Tax of human T-cell leukemia virus type I. Oncogene 20: 2055-2067, 2001.

22. Nicot C, Mahieux R, Takemoto $S$ and Franchini G: Bcl- $X_{\mathrm{L}}$ is up-regulated by HTLV-I and HTLV-II in vitro and in ex vivo ATLL samples. Blood 96: 275-281, 2000.

23. Krueger A, Fas SC, Giaisi M, Bleumink M, Merling A, Stumpf C, Baumann S, Holtkotte D, Bosch V, Krammer PH and Li-Weber M: HTLV-1 Tax protects against CD95-mediated apoptosis by induction of the cellular FLICE-inhibitory protein (c-FLIP). Blood 107: 3933-3939, 2006.

24. Wäldele K, Silbermann K, Schneider G, Ruckes T, Cullen BR and Grassmann R: Requirement of the human T-cell leukemia virus (HTLV-1) tax-stimulated HIAP-1 gene for the survival of transformed lymphocytes. Blood 107: 4491-4499, 2006.

25. Kawakami A, Nakashima T, Sakai H, Urayama S, Yamasaki S, Hida A, Tsuboi M, Nakamura H, Ida H, Migita K, Kawabe Y and Eguchi K: Inhibition of caspase cascade by HTLV-I tax through induction of NF- $\kappa$ B nuclear translocation. Blood 94: 3847-3854, 1999.

26. Dolcet X, Llobet D, Pallares J and Matias-Guiu X: NF-kB in development and progression of human cancer. Virchows Arch 446: 475-482, 2005.

27. Sun S-C and Yamaoka S: Activation of NF- $\kappa B$ by HTLV-I and implications for cell transformation. Oncogene 24: 5952-5964, 2005.

28. Hayden MS and Ghosh S: Shared principles in NF- $\mathrm{B}$ signaling. Cell 132: 344-362, 2008.

29. Ong P-L, Weng B-C, Lu F-J, Lin M-L, Chang T-T, Hung R-P and Chen $\mathrm{C}-\mathrm{H}$ : The anticancer effect of protein-extract from Bidens alba in human colorectal carcinoma SW480 cells via the reactive oxidative species- and glutathione depletion-dependent apoptosis. Food Chem Toxicol 46: 1535-1547, 2008.

30. Hussain AR, Ahmed M, Al-Jomah NA, Khan AS, Manogaran P, Sultana M, Abubaker J, Platanias LC, Al-Kuraya KS and Uddin S: Curcumin suppresses constitutive activation of nuclear factor- $\kappa \mathrm{B}$ and requires functional Bax to induce apoptosis in Burkitt's lymphoma cell lines. Mol Cancer Ther 7: 3318-3329, 2008.

31. Hall WW and Fujii M: Deregulation of cell-signaling pathways in HTLV-1 infection. Oncogene 24: 5965-5975, 2005.

32. Kusano A, Seyama Y, Usami E, Katayose T, Shibano M, Tsukamoto K and Kusano G: Studies on the antioxidant active constituents of the dried powder from Bidens pilosa $\mathrm{L}$. var. radiata $\mathrm{SCH}$. Nat Med (Tokyo) 57: 100-104, 2003. 
33. Kroemer G and Reed JC: Mitochondrial control of cell death. Nat Med 6: 513-519, 2000.

34. Deveraux QL, Roy N, Stennicke HR, Van Arsdale T, Zhou Q, Srinivasula SM, Alnemri ES, Salvesen GS and Reed JC: IAPs block apoptotic events induced by caspase- 8 and cytochrome $c$ by direct inhibition of distinct caspases. EMBO J 17: 2215-2223, 1998.

35. Shin S, Sung B-J, Cho Y-S, Kim H-J, Ha N-C, Hwang J-I, Chung C-W, Jung Y-K and Oh B-H: An anti-apoptotic protein human survivin is a direct inhibitor of caspase- 3 and -7 . Biochemistry 40 : 1117-1123, 2001.

36. Thome M and Tschopp J: Regulation of lymphocyte proliferation and death by FLIP. Nat Rev Immunol 1: 50-58, 2001.

37. Zhu L, Fukuda S, Cordis G, Das DK and Maulik N: Anti-apoptotic protein survivin plays a significant role in tubular morphogenesis of human coronary arteriolar endothelial cells by hypoxic preconditioning. FEBS Lett 508: 369-374, 2001.
38. Hess J, Angel P and Schorpp-Kistner M: AP-1 subunits: quarrel and harmony among siblings. J Cell Sci 117: 5965-5973, 2004.

39. Shaulian E and Karin M: AP-1 in cell proliferation and survival. Oncogene 20: 2390-2400, 2001.

40. Brooks AR, Shiffman D, Chan CS, Brooks EE and Milner PG: Functional analysis of the human cyclin D2 and cyclin D3 promoters. J Biol Chem 271: 9090-9099, 1996.

41. Mathas S, Hinz M, Anagnostopoulos I, Krappmann D, Lietz A Jundt F, Bommert K, Mechta-Grigoriou F, Stein H, Dörken B and Scheidereit C: Aberrantly expressed c-Jun and JunB are a hallmark of Hodgkin lymphoma cells, stimulate proliferation and synergize with NF-кB. EMBO J 21: 4104-4113, 2002. 